\title{
Antimicrobial Activity Of Sphenocentrum Jollyanum And Mangifera Indica Linn On Salmonella Typhi
}

\author{
*Koleosho A.T., *Jose A.R., ${ }^{\circledR}$ Oyibo P.G., *Roland-Ayodele M.A. and \\ "Uloko Mabel E. \\ *Dept of Nutrition \&Dietetics, and Dept of Science Lab Tech Rufus Giwa Polytechnic, PMB 1019, Owo, Ondo \\ State, Nigeria. \\ ${ }^{\circledR}$ Dept of Community Medicine, Delta State University, Abraka. \\ ${ }^{\#}$ Dept of Home Economics, Federal College of Education (Tech), Asaba, Delta State, Nigeria.
}

\begin{abstract}
This study was carried out to assess the antimicrobial activities of Sphenocentrum jollyanum and Mangifera indica extract on Salmonella typhi. The antimicrobial activities of these plant extract $<50 \%$ ethanol was tested against Salmonella typhi mostly belongs to pathogenic bacteria, by agar well diffusion method. The crude extracts showed a broad extract spectrum of an antibacterial activity inhibiting the Salmonella typhi. Minimal inhibitory concentration of the extract against the test organism (Salmonella typhi) was also studied by observing their growth on the agar well diffusion containing the ethanoic extract at different concentration. The extract was effective against Salmonella typhi. The significance of this study was to search for development of plant extract for industrial drug enhancement.
\end{abstract}

\section{Introduction}

A medicinal plant is any plant in which one or more of its organs contain substances that can be used for therapeutic purposes in which are precursors for synthesis of useful drugs. Plant derived substances have recently become of immense interest owning to their versatile applications.

Medicinal plants are the wealthiest bio-resources of drugs of traditional system of medicines, modern medicines, neutraceutical, food supplements, folk medicines, pharmaceutical intermediates and chemical activities for synthetic drugs ${ }^{(16)}$. According to $\mathrm{WHO}{ }^{(27)}$, medicines got from plant extracts continue to provide health coverage for over $80 \%$ of the world's population, especially in developing countries.

Many traditional medicines are still included as part of the habitual treatment of various maladies. The fact that traditional knowledge systems are largely oral and not written, accentuates the fragility of this type of indigenous knowledge, the change in sociopolitical climate in the last few years have resulted in increased awareness of use of herbs in therapy. Plant recognized to be valuable as food, medicine, shelter, etc. from the link between communities and their surrounding vegetation. This estimated that today, plant materials are present or have provided this model $50 \%$ western drug ${ }^{(21)}$.

One interesting features of the traditional herbal medicines is the frequent use of combinations of plants part rather than individual plant or parts for the preparing decoctions. The efficacy of such preparation may be a result of an additives or synergistic effects of the components and the primary benefits of using plants derived medicine are relatively safer than synthetic alternative offspring, profound therapeutic benefit and more affordable treatment. The root and leaves of the plants are use against variety of diseases such as thyphoid fever, gastroenteritis, dysentery, malaria, eczema, and others which are typical diseases of tropical countries ${ }^{(25)}{ }^{(18)}$.

Antimicrobial is a substance that acts to inhibit the growth of harmful micro-organisms or act to destroy them, such as bacteria, fungi, protozoans. Antimicrobial can either be bactericidal or bacteriostatic. Bactericidal is a smallest amount chemical substance that kills $99.9 \%$ of bacterial growth, where as, Bacteriostatic are lowest substance that can prevent the growth of bacteria.

The history of antimicrobials begins with the observation of Pasteur and Joubert, who discovered that one type of bacteria could prevent the growth of another, they did not know at that time that, the reason why one bacterium fails to grow, was that the other bacterium was producing an antibiotic. Technically, antibiotics are those substances produced by one micro-organism that kill or prevent the growth of another micro-organism.

The persistent increase in antibiotic strains of organisms have led to the development of more potent antibiotic such as $3^{\text {rd }}$ and $4^{\text {th }}$ generation of cephalosporius by pharmaceutical company ${ }^{(19)}$. Many published reports have shown the effectiveness of traditional herbs against micro-organisms. As a result, plants are one of the bedrocks for modern medicines to attain a new principle ${ }^{(8)}$.

Sphenocentrum jollyanum, a perennial plant, is an erect shrub that belongs to the family Menispermaceae ${ }^{(17)}$. It is a deep rooted plant that grows up to $1.5 \mathrm{~m}$ high having few branches. The plant is traditionally used as remedy for feverish condition, cough, jaundice, breast swelling related to menstrual cycles, 
as an aphrodisiac and other inflammatory conditions such as tumours ${ }^{(10)}{ }^{(19)}$. Studies have shown that Sphenocentrum jollyanum root and leaves possessed significant anti-inflammatory, anti-angiogenic, antipyretic and analgesic activities ${ }^{(14)(17)}$. It has also been found to be potent against polio type-2 virus ${ }^{(13)}$.

The chemical constituents have also been investigated. A bitter tasting terpenoid compound had earlier been isolated from the root ${ }^{(10)}$. Other reports showed the plant root to be rich in tannins and saponins ${ }^{(13)}$.

Mangifera indica linn, is a large evergreen tree, long living, that grows up to $10-45 \mathrm{~m}$ high with a strong trunk and heavy crown. Native from tropical Asia, it has been introduced wherever the climate is sufficiently warm and damp and is now completely naturalized in many parts of the tropics and subtropics ${ }^{(24)}$. This plant has been an important herb in the Ayurvedic and indigenous medical systems for over 4000 years. Mangifera indica linn, belong to the family of Anacardiacaea and the genus Magnifera, which consists of about 30 species of tropical fruiting trees. Many natural substances of plant origin are reported to be biologically active, endowed with anti-microbial allelopathic and antioxidant properties ${ }^{(3)}$.

Most parts of the tree are used medicinally, and the bark also contains tannins, which are used for the purpose of dyeing. The root and barks of mango are astringent, acrid, anti-inflammatory and constipating. The plant is widely used in the traditional medicinal system of India and is considered as a king of fruit in their delicacy.

Salmonella typhi is a bacterium that causes thyphoid fever (enteric fever). Thyphoid fever is a global infection with a fatality rate of $10 \%$. The disease is a cause of concern and a major public health problem in developing countries (Asia, Africa), especially in Nigeria due to poor sanitary conditions and lack of or inadequate potable water ${ }^{(2)}{ }^{(7)}$. The World Health Organization ${ }^{(27)}$ estimated an annual infectious rate of 21.6 million and approximately death rate of 600,000 with the highest percentage in Africa and Asia. Resistance to a number of antibiotics among Salmonella typhi has become a serious problem. Strains of Salmonella typhi resistant to chloramphenicol and other recommended antibiotics have been identified in several parts of Latin America, Asia and Africa ${ }^{(26)(5)}$. Development of multi-drug resistance by the bacterium has further complicated the problem. Antibiotic resistance is further accelerated due to irrational use of antibiotics and overall. Counterpurchase attitude by the populace, which is a very common phenomenon in Africa.

Adequate documentation of resistant profile of these organisms is also lacking ${ }^{(1)}$. Infections caused by resistant salmonella and indeed other pathogens result in significant morbidity and mortality and contribute to escalating healthcare costs worldwide.

Despite the availability of newer antibiotics emerging, antimicrobial resistance has become an increasing problem in many pathogens throughout the world ${ }^{(22)}$ (12). For practicing physicians, clinical microbiologists and public health officials, knowledge of local antimicrobial resistance pattern is essential to guide empirical and pathogen-specific therapy. This information is also critical for optimal decisions regarding hospital formulatory and infection control policies, for the rational formulation of public healthcare policies and national and international research agendas in this area ${ }^{(6)}$.

Unfortunately, data regarding endemic antimicrobial resistance are unavailable in many parts of the world, especially from areas where over-the-counter antibiotic use is common ${ }^{(15)}$.

This work aims to determine the antimicrobial efficacy of the root extract of Sphenocentrum jollyanum and Mangifera indica on Salmonella typhi.

\section{Materials And Methods}

Autoclave, incubator, McCartney bottle, forceps, cork borer, Ethanol, inoculating loop, test-tubes, Nutrient agar, conical flasks, distilled water, muslin cloth, measuring cylinder, cotton wool, and spirit lamp.

\section{Sterilization of Materials}

All the glasswares were washed with detergent and rinsed with distilled water. They were air-dried before wrapping with aluminium foil and sterilized in hot air at $170^{\circ} \mathrm{C}$ for 2 hours.

Media (Nutrient agar) was sterilized in an autoclave at temperature of $121^{\circ} \mathrm{C}$ for 15 minutes. Cork borer, glass rod and forceps were sterilized by dipping in $70 \%$ ethanol and were flamed. The inoculating loop was sterilized by heating to redness using naked flame before and after each use.

\section{Sources of Plant}

Fresh plant roots of Sphenocentrum jollyanum and Mangifera indica linn were collected from a farmland in Akure, Ondo State.

\section{Preparation of the Root Extract}

The fresh root was washed, chopped into pieces and dried in an oven regulated at $40^{\circ} \mathrm{C}$. The dried root was pulverized with a hammer-mill to obtain a coarse powder and was sieved with $0.2 \mathrm{~m}$ mesh and the sample was stored in a clean container. 
Procedure:

- The sample was soaked into $200 \mathrm{ml}$ of ethanol.

- It was stirred for 2 hours, at the interval of 30 minutes.

- $\quad$ The extracted material was filtered by using Whatman filter paper No.4

- The supernatant was evaporated by air-drying which takes 2-3 weeks and it was ensured that there is no contamination.

\section{Test Organisms Used}

Salmonella typhi was collected from the Department of Microbiology, Federal Medical Centre, Owo, Ondo State. The organism was cultured and maintained at $4{ }^{\circ} \mathrm{C}$ on nutrient agar slant.

\section{Antimicrobial Activity Test}

The antimicrobial activity of plant extract can be determined by using Agar well diffusion technique (20). To apply the micro-organism as used by Rehm and Espig ${ }^{(23)}$, cork boring method was used for extract application.

The test organism was aseptically introduced into a sterile Petri-dish from broth culture. A Nutrient agar of about $20 \mathrm{ml}$ was aseptically prepared by using an autoclave at temperature of $121^{\circ} \mathrm{C}$ for 15 minutes and it was allowed to cool to $45^{\circ} \mathrm{C}$. The sterilized nutrient agar was aseptically poured into a sterilized Petri-dish containing test organism and was gently rotated for distribution of the organism.

The agar plate was allowed to solidify. After it has been solidified, a sterilecork borer was used to punch out 5 holes, creating a well at about $7.0 \mathrm{~mm}$ diameter on the agar plate. A control well was at the centre by using the extracting solvent of the extract. Then the holes were filled with different concentration of the extract by using sterile syringe and needle.

Incubation was done at $37^{\circ} \mathrm{C}$ for $24-48$ hours. Each experiment was carried out in duplicate and the means of the diameter of zone of inhibition was determined (zone of inhibition was measured in millimeter to the nearest $0.1 \mathrm{~mm})^{(11)}$.

\section{Minimum Inhibitory Concentration (MIC) and Minimum Bactericidal Concentration (MBC) of the Extracts}

Minimum Inhibitory Concentration (MIC) is the smallest amount of agent that is needed to inhibit the growth of micro-organisms. The MIC of the extract was determined by using the broth dilution technique to know the effect on micro-organisms. The MIC also helps to measure more exactly the concentration of antibiotic necessary to inhibit growth of standardized inoculums under defined conditions ${ }^{(9)}$.

Serial dilution of the extract in liquid medium was prepared. The culture was then challenged with small inoculums of an overnight broth culture of the test organisms. The culture was incubated at $37^{\circ} \mathrm{C}$ for 48 hours. The smallest concentration that inhibits the growth was taken as the MIC.

The Minimum Bactericidal Concentration (MBC) is the lowest concentration of the antibacterial agent that kill at least $99.9 \%$ of the test organism ${ }^{(9)}$.

The sample was taken from plate, about $0.5 \mathrm{ml}$ was removed from the test tube with no visible growth, the lowest concentration of the agent prevent the growth of less than $0.1 \%$ of the test organism on the recovery plate, was then taken as MBC value for the extract.

\section{Results}

Table 1: Antimicrobial activities of the root extract of Sphenocentrum jollyanum and Mangifera indica Zone of inhibition (mm)

\begin{tabular}{ll}
\hline Concentration $(\mathbf{g} / \mathbf{m l})$ & Salmonella typhi (zone of inhib. $(\mathbf{m m})$ \\
\hline 1 & 0.4 \\
2 & 0.6 \\
3 & 0.9 \\
Antibiotic & \\
Gentamycin & 10 \\
Gram $(\underline{+})$ & - \\
\hline
\end{tabular}

Incubation temperature: $37^{\circ} \mathrm{C}$

Incubation period: 24 hours, Negative control: Ethanol 
Table 2: The Minimum Inhibitory Concentration values of Sphenocentrum jollyanum and Mangifera indica extract in $(\mathrm{mg} / \mathrm{ml})$ against Salmonella typhi.

\begin{tabular}{lll}
\hline Bacterium & MBC & MIC \\
\hline Salmonella typhi & $250(\mathrm{mg} / \mathrm{ml})$ & $100(\mathrm{mg} / \mathrm{ml})$ \\
\hline
\end{tabular}

Incubation temperature: $37^{\circ} \mathrm{C}$

Incubation period: 24 hours, Negative control: Ethanol

\section{Discussion}

Antibacterial effect of Sphenocentrum jollyanum and Mangifera indica against Salmonella typhi was recorded and the effect of the plant extract on test bacterium was shown in tables 1 and 2 above. The positive control (Gentamycin) produced inhibitory zone against Salmonella typhi.

From this investigation, it was observed that the two plants extract were effective against gram negative bacteria (Salmonella typhi). It may be due to the presence of different constituents of the extracts saponin, terpenes, flavonoid, tannins (Dwama-badu, 2006; Moody et al, 2005).

The result clearly revealed that the ethanolic extract inhibits the test bacterium (Salmonella typhi) at all concentrations $1 \mathrm{~g} / \mathrm{ml}, 2 \mathrm{~g} / \mathrm{ml}$ and $3 \mathrm{~g} / \mathrm{ml}$; but $3 \mathrm{~g} / \mathrm{ml}$ had the highest zone of inhibition. The MIC and MBC value were $100 \mathrm{mg} / \mathrm{ml}$ to $250 \mathrm{mg} / \mathrm{ml}$ respectively. However, the modes of action of ethanolic are dose-dependent and bacteriostatic.

\section{Conclusion}

This study was a preliminary evaluation of antimicrobial effect of the plants. It indicated that Sphenocentrum jollyanum and Mangifera indica have the potential antimicrobial activities that could be used in treatment of human disease. This result revealed that the plant extract was effective against Salmonella typhi.

Most micro-organisms have developed resistance to the orthodox drugs therefore herbs can be used. Instead of going for an expensive orthodox drug which may not be easy to afford together with their side effects, the available herbs are very effective as that of orthodox drugs with fewer side effects. It does not cost people anything and can be easily gotten anywhere and everywhere.

The continued use of traditional medicine of these plants is therefore encouraged while it is suggested that further work should be carried out to isolate, purify and possibly characterize the active constituents responsible for the activity of these plants. Also, additional work should be embarked upon with a view to elucidating the possible mechanism of action of these extracts.

In conclusion, the plant extracts can be developed for industrial drug enhancement.

\section{References}

[1] Alawode AO (2003). Antibiotics and drug resistance problem; A matter of public concern. IPAN News 4(4):9

[2] Anita S, Indrayan AK, Guleria BS, Gupta CP (2002). Antimicrobial Activity of Dye of Caesalpinia sappan (Patang/Brazil wood). Indian Journal Microbiol, 42:359-360

[3] Azoro C (2002). Antibacterial activities of crude extract of Azadirachita indic on Salmonella typhi, World Journal of Biotechnology, 3:347-351

[4] Barreto JC, Trevisan MTS, Hull WS, Erben G, De Brito ES, Owen RW (2008). Characterization and quantitation of polyphenolic compounds in bark, kernel, leaves and peel of mango (Mangifera indica L.) Journal of Agricultural and Food Chemistry, 56(14):5599-5610

[5] Benoit D, Renaud L, Daniele M, Anne B, David B, Michael RM, Elisabeth C, Anel C (2003). Variant Salmonella Genomic Island 1. Antibiotic Resistance Gene cluster in Salmonella enterica serovar. 9(5):585-591

[6] Cletus Nze A (1996). Therapeutic basis of clinical pharmacy in the tropics, $2^{\text {nd }}$ ed. Optimal Publishers, Enugu, Nigeria, pp.135-138.

[7] Doughari JH (2005). A comparative study on effect of crude extract of some local medicinal plants and some selected antibiotic on Salmonella typhi pp.1-15. MSc. Thesis, Federal University of Technology Yola, Adamawa State, Nigeria, pp.1-4

[8] Evans EE, Banso A, and Samuel OA (2002). Efficacy of some nine medicinal plants against Salmonella typhi and in vitro study. $J$ Ethnopharmacol, 80:82-100

[9] Geo F, Brooks JSB and Stephen OA (2001). Jawetz, Med. Clinic and Adelbeog's Medical Microbiology, $22^{\text {nd }}$ Ed. Pp.607

[10] Iwu MM (1993). Handbook of African medicinal plants. CRC press, Boca Raton, Florida, United States p.464

[11] Jonathan SG, and Fasidi IO (2003). An original article on Antimicrobial activities of two Nigerian edible macro-fungi Lycoperdon pusilum and Lycoperdon giganteum. African Journal of Biomedical Research, 6:85-9

[12] Keith P, and John RK (2005). Hidden epidemic of macrolide-resistant pneumococci. Emerg. Infect. Dis, 11(6):802-807

[13] Moody JO, Roberts VA, Connolly JD and Houghton PJ (2005). Anti-inflammatory activities of the methanol extracts and an isolated furanoditerpene constituent of Sphenocentrum jollyanum pierre (Menispermaceae). Journal of Ethnopharmacology 104(12):87-91.

[14] Muko KN, Ohiri PC, Ezegwu CO (1998). Antipyretic and analgesic activities of Sphenocentrum jollyanum. Niger J Nat Prad Med 2:52-53

[15] Naselt P, Rao PI, Kurup PA (1999). Pterygospermin, the antibiotic principle of Moringa pterygosperma Gaetn. Indian Journal of Pharmacy, 15(12):315

[16] Ncube NS, Afolayan AJ, Okoh AI (2008). Assessment techniques of Antimicrobial properties of natural compounds of plant origin: current methods and future trends. African Journalof Biotechnology 7(12):1797-1806 
[17] Nia RJ, Paper DH, Essien EE, Iyadi KC, Bassey AI (2004). Evaluation of the anti-oxidant and anti-angiogenic effects of Sphenocentrum jollyanum pierre, African J Biomed Res, 7:129-132

[18] Nick A, Radi T, and Sticher (1995). Biological screening of traditional medicinal plants from Papua New Guinea. $J$ Ethnopharmacol 49:149-156

[19] Odugbemi T (2006). Outline and pictures of medicinal plants from Nigeria, University of Lagos Press, pp.53-64

[20] Okeke MI, Iroegbu CU, Eze EN, Okoli AS and Esimore CO (2002). Evaluation of extracts of the root of Landolphia owerrience for antibacterial activity. Journal of Ethnopharmacology, 78:119-127

[21] Pelczar MJ, Chan ECS, and Krieg NR (1993). Microbiology concepts and applications. McGraw Hill Inc. New York, $22^{\text {nd }}$ Ed, p.13

[22] Pfaller MA, Jones RN, Marshall SA, Coffman SL, Hollis RJ, Edmond M (1997). Inducible Amp-CB-lactamase producing Gramnegative bacilli from blood stream infections: frequency, antimicrobial susceptibility, and molecular epidemiology in a national surveillance programme (scope).

[23] Rehm S, and Espig G (2001). The cultivated plant on the tropics and subtropics. Verlag joset margrats welker sheim 7:18-21

[24] Ross IA (1999). Medicinal plants of the world, chemical constituents, traditional and modern medicinal uses, Human Press, Totowa, pp.197-205

[25] Sofawora A (1993). Medicinal plants and traditional medicines in Africa. Chic Hester John, Willey \& Sons NY, p.256

[26] Threfall EJ, Ward LR, Skinner JA, Smith HR (2001). Ciprofloxacin in Typhoid Fever. Lancet 35(4):164.

[27] WHO (2002). Traditional medicine: Growing needs and potential. WHO policy prospectives on medicines. World Health Organization, Geneva, pp.1-6 